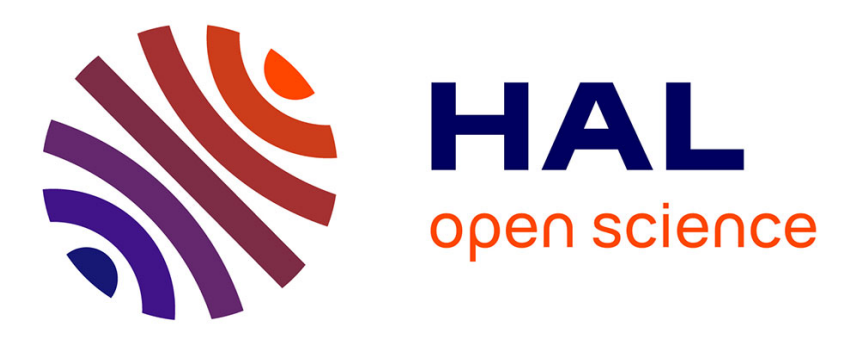

\title{
Rádios Indígenas: Brazil's Indigenous Language Broadcasting Landscape
}

Natália Oliveira Ferreira, Mark Turin

\section{To cite this version:}

Natália Oliveira Ferreira, Mark Turin. Rádios Indígenas: Brazil's Indigenous Language Broadcasting Landscape. Journal of Radio \& Audio Media, 2021, pp.1-25. 10.1080/19376529.2021.1998066 . halshs-03519958

\section{HAL Id: halshs-03519958 \\ https://shs.hal.science/halshs-03519958}

Submitted on 10 Jan 2022

HAL is a multi-disciplinary open access archive for the deposit and dissemination of scientific research documents, whether they are published or not. The documents may come from teaching and research institutions in France or abroad, or from public or private research centers.
L'archive ouverte pluridisciplinaire HAL, est destinée au dépôt et à la diffusion de documents scientifiques de niveau recherche, publiés ou non, émanant des établissements d'enseignement et de recherche français ou étrangers, des laboratoires publics ou privés. 


\section{Rádios Indígenas: Brazil's Indigenous Language Broadcasting Landscape}

\section{Natália Oliveira Ferreira \& Mark Turin}

To cite this article: Natália Oliveira Ferreira \& Mark Turin (2021): Rádios Indígenas: Brazil's Indigenous Language Broadcasting Landscape, Journal of Radio \& Audio Media, DOI: 10.1080/19376529.2021.1998066

To link to this article: https://doi.org/10.1080/19376529.2021.1998066

\section{Published online: 17 Dec 2021}

Submit your article to this journal $\sqsubset$

山ll Article views: 37

Q View related articles $\longleftarrow$

View Crossmark data 


\title{
Rádios Indígenas: Brazil's Indigenous Language Broadcasting Landscape
}

\author{
Natália Oliveira Ferreira (D) and Mark Turin (D)
}

\begin{abstract}
This article offers a critical review of Brazil's Indigenous language broadcasting landscape, from traditional analogue transmission to podcasts and online radio. The study introduces Brazil's Indigenous linguistic diversity and locates the current vitality of Indigenous languages within Brazil's constitutional provisions and broadcasting legislation that both support and impede programming in languages other than Portuguese. Following an assessment of media penetration and uptake, and a contrastive review of four Brazilian radio stations that have either substantial Indigenous content or a dedicated focus on Indigenous issues, the article concludes with an assessment of the outlook and challenges for programming in this sector.
\end{abstract}

A rádio sempre foi um dos meios de comunicação mais ouvidos na Amazônia por causa das distâncias geográficas e obstáculos logísticos. Com a popularização da internet, esperava-se que esse meio de comunicação fosse "morrer," mas ele acabou reinventando. "É espantoso como a rádio deixou de ser aquele veículo que tinha uma chiadeira para pegar e hoje chega a qualquer lugar, qualquer beco, gueto, basta ter internet" (Santos, 2019) ${ }^{1}$

Our translation: Radio has always been one of the most listened-to media in the Amazon because of geographical distance and logistical obstacles. With the popularization of the internet, it was expected that this communication medium would "die," but instead, it ended up being reinvented. "It is amazing how radio ceased to be the device that had a buzzing static when you turned it on, and today reaches anywhere, any alley and any ghetto, you just need to have [access to the] internet"

Radio in Brazil occupies a particular place in the social and public imagination (Prado, 2012). As has been robustly documented by contributors to this journal (Anderson, Backhaus, Fox, \& Bedford, 2020; Chikaipa \& Gunde, 2020; Costa Alves, 2020; Demuyakor, 2021; Jimenez, 2019; Steinfeld \& Laor, 2019; and many others), radio remains a remarkably resilient 
communications medium. In addition, radio warrants deeper examination as a vehicle for the transmission and revitalization of historically marginalized and Indigenous languages (Danos \& Turin, 2021) as well as how this medium has contributed to the historical suppression, ongoing marginalization and assimilation of minority voices.

In this contribution, we offer a preliminary assessment of the Brazilian broadcasting landscape with a specific focus on how, where and when analogue and digital radio is being used as a tool for sharing stories, songs, and conversations in Indigenous languages. In so doing, we assess the structural conditions within Brazil that both support and impede developments in Indigenous-language radio programming, both on air and online. Keeping with emerging conventions in Indigenous studies, we write Indigenous with a capital "I" throughout this contribution and in all of our other work (see Weeber, 2020). ${ }^{2}$

Following Danos and Turin (2021), we take as our departure point an understanding that radio is particularly well-suited for Indigenous language programming for three interconnected reasons. First, compared to other broadcast media, the cost of radio operations is low. Second, radio is increasingly consumed asynchronously, meaning that programs can be listened to at any time (through repeats, podcasts, downloads, and streaming services). Third, as a technology, radio is distinctive for not being exclusive or allconsuming, meaning that a listener can be actively involved in another activity at the same time as engaging with a radio broadcast, allowing versatility and flexibility in a manner that other communications and entertainment media do not support.

The geographical focus of our paper is Brazil, a country home to great linguistic diversity, in particular in the Amazonian regions. In this article, we examine how the large number of Indigenous languages spoken and signed in Brazil intersects with the further development and rollout of Indigenous language broadcasting. Given the dual constraints of limited resources and a current federal government openly hostile to Indigenous issues (Phillips \& Milhorance, 2021), our preliminary assertion is that Brazil's linguistic diversity combined with the high number of under-documented Indigenous languages spoken within its borders and a highly bureaucratic and even alienating registration process for legal transmission (see section 6) pose challenges to the further development and implementation of Indigenous language broadcasting.

Unlike Hawai'i or Aotearoa New Zealand, each of which are generally identified as being home to only one primary Indigenous language (Ministry for Culture and Heritage, 2020; Wilson, 2014), or Canada which now has federal legislation in support of the revitalization of many Indigenous languages spoken across the nation (Bliss, Gessner, Herbert, \& Parker, 2020), Brazil is weaker in terms of policy and support for Indigenous language 
media, while at the same time very rich in linguistic diversity. In terms of Indigenous radio broadcasting in particular, Mexico offers a welcome point of comparison, being both a fellow Latin American country home to considerable Indigenous linguistic diversity (68 languages, with 364 variants) and multiple Indigenous radio stations, most of which are located in the south. However, only a few of these Indigenous radios are fully licensed to broadcast in Mexico, and the majority continue to operate without a license and broadcast independently (Tron, 2021).

\section{Brazil's Linguistic Diversity}

According to Brazil's 2010 census, the country is home to 305 distinct Indigenous ethnic communities totaling 896,917 people who self-identify as Indigenous (IBGEeduca, 2021). The same source reveals that $57.7 \%$ of the Indigenous population live in locations that are officially recognized as Indigenous lands and $42.9 \%$ of the Indigenous population report speaking an Indigenous language. The impact of national education, media and language campaigns can be seen in the fact that $76.9 \%$ of the Indigenous population of Brazil report speaking Portuguese (IBGEeduca, 2021).

This statistical specificity aside, it may be surprising to readers not otherwise specialized in language that there is no agreement about the number of languages spoken in Brazil, or, for that matter, across the world. Most scholars agree that there are upwards of 7,100 living languages spoken and signed around the globe as naturally occurring speech forms (Turin, 2019; Turin \& Pine, 2019), although that number varies widely depending on who is doing the counting and the intent behind the enumeration. When the Portuguese explorer Pedro Álvares Cabral arrived in Brazil in AD 1500, sources indicate that more than one thousand native Indigenous languages were spoken in what has come to be known as Brazilian territory (Rodrigues, 1998, as cited by Massini-Cagliari, 2006, p. 66). The Ethnologue, a contested source given its close association with Christian evangelical activity and missionary work, reports that Brazil is currently home to 238 languages, of which 218 are living (Eberhard, Simons, \& Fennig, 2021). The Ethnologue also classifies a further 20 languages as "extinct" - a highly problematic term (see Pine \& Turin, 2017, for more context on why using such labels can unwittingly perpetuate that which they seek only to describe). According to the Ethnologue, of the living languages identified as currently spoken in Brazil, 201 are Indigenous and 17 are non-Indigenous (Eberhard et al., 2021).

Both lower and higher estimates for the number of languages spoken in Brazil are in circulation, with Brazilian sources differing widely. Povos Indígenas no Brasil (PIB, Indigenous Peoples in Brazil), a well-regarded national source for the collation, analysis, and dissemination of authoritative information about Indigenous peoples in Brazil, identifies 160+ languages 
(PIB, n.d.), while the Instituto Brasileiro de Geografia e Estatística (IBGE, the Brazilian Institute of Geography and Statistics) counts 274 (Instituto Brasileiro de Geografia e Estatística [IBGE], 2012), following the 2010 census. ${ }^{3}$ Working from the same 2010 population census but leveraging additional data from FUNAI, ${ }^{4}$ Crevels $(2012$, p. 1) identifies Brazil as being home to 177 Indigenous languages. Given the great range in the number of Indigenous languages identified as spoken in Brazil, we offer Table 1 below to assist readers in comparing these varying statistics, their sources and date of publication.

In all of this classificatory confusion, "one tenet of the linguistic folklore of Brazil is that there are 180 indigenous languages. No one repeating this number can explain what it means exactly or what the criteria are for grouping variants into one language" (Moore \& Galucio, 2016, p. 44). Whatever the actual number, one point is beyond debate: the vast majority of languages native to Brazil are spoken by members of Indigenous communities. These same Indigenous communities face multiple threats to their livelihoods and sustainable futures through violent resource extraction (Phillips \& Milhorance, 2021), habitation decimation (Associated Press in Rio de Janeiro, 2021; Krenak, 2021) and a federal government deeply hostile to Indigenous cultural and territorial rights (Naknanuk, 2021). Brazil's Indigenous communities are under sustained pressure, and so too are their languages, with the Ethnologue identifying 99 languages as "dying" according to the Expanded Graded Intergenerational

Table 1 Number of Indigenous Languages Reported Spoken in Brazil, Organized by Source, Author and Year

\begin{tabular}{|c|c|c|c|}
\hline Source & Author(s) & Date & $\begin{array}{l}\text { Number of Indigenous } \\
\text { languages reported in Brazil }\end{array}$ \\
\hline Línguas & PIB & $\mathrm{n} / \mathrm{a}$ & $160+$ \\
\hline $\begin{array}{l}\text { Línguas indígenas: } 500 \text { anos de } \\
\text { descobertas e perdas }\end{array}$ & Rodrigues, A. D. I. & 1993 & $\sim 180$ \\
\hline $\begin{array}{l}\text { Language policy in Brazil: } \\
\text { Monolingualism and linguistic } \\
\text { prejudice }\end{array}$ & Massini-Cagliari, G. & 2004 & 170 \\
\hline Censo 2010 & IBGE & 2012 & 274 \\
\hline $\begin{array}{l}\text { Language endangerment in South } \\
\text { America: The clock is ticking. }\end{array}$ & Crevels, M. & 2012 & 177 \\
\hline $\begin{array}{l}\text { Linguística: as línguas indígenas do } \\
\text { Brasil. }\end{array}$ & Rodrigues, A. D. I. & 2015 & $120-150$ \\
\hline $\begin{array}{l}\text { Perspectives for the documentation } \\
\text { of indigenous languages in Brazil }\end{array}$ & $\begin{array}{l}\text { Moore, D. \& Galucio, } \\
\text { A. V. }\end{array}$ & 2016 & 180 \\
\hline $\begin{array}{l}\text { Indigenous language policies in } \\
\text { Brazil: Training indigenous people } \\
\text { as teachers and researchers }\end{array}$ & $\begin{array}{l}\text { Cabral, A. S. A. C., de } \\
\text { Araújo Sampaio, } \\
\text { W. B., \& Sinha, } \\
\text { V. D. S. }\end{array}$ & 2016 & $\begin{array}{l}220 \text { (Indigenous }+ \text { immigrant } \\
\text { languages) }+\sim 40 \text { (from } \\
\text { isolated communities) }\end{array}$ \\
\hline Ethnologue - Brazil & $\begin{array}{l}\text { Eberhard, D.M., Simons, } \\
\text { G. F., and Fennig } \\
\text { C. D. }\end{array}$ & 2021 & 201 \\
\hline
\end{tabular}


Disruption Scale or EGIDS (Eberhard et al., 2021). ${ }^{5}$ At the same time, there are impressive local efforts underway to both document and revitalize Indigenous languages spoken in Brazil, with communities establishing projects and developing programs to revive and reclaim threatened linguistic practices and cultural traditions (cf. Sarah Shulist, 2017, for an ethnographic study of urban Indigenous communities of the Rio Negro region).

\section{Language Policy and Planning in Brazil}

The constitutional and legal provisions in support of Brazil's Indigenous peoples and their languages are neither encouraging nor can they be described as progressive. While Article 231 of the Brazilian Constitution notes that "Indigenous people shall have their social organization, customs, languages, creeds and traditions recognized, as well as their original rights to the lands they traditionally occupy" (Superior Tribunal Federal [STF], 2020), there is still no federal legislation that guarantees resources for, or enshrines the linguistic rights of, Brazil's Indigenous peoples. It is encouraging that across six municipalities in the country, eight Indigenous languages have received regional official status which, on paper at least, situate them at the same level of structural importance as Portuguese in those regions. These languages are Tukano, Baniwa, Nheengatu (São Gabriel da Cachoeira, in the region of Rio Negro, Amazonas state); Guarani (Tacuru, in Mato Grosso do Sul state); Akwê Xerente (Tocantínea, Tocantins state); Macuxi and Wapichana (Bonfim and Cantá, both in Roraima state); and Ticuna/Tikuna (Santo Antônio do Içá, in Amazonas state) (Morello, 2021). Aside from these localized examples, the wider legislative framework remains mostly unsupportive of Indigenous languages and linguistic rights, with no specific laws designed to stimulate Indigenous language learning nor concrete plans for language revitalization.

In terms of salient legislation that would promote linguistic rights, Brazil federal Bill 3074/2019 was introduced in May 2019, with the stated goal of making Indigenous languages co-official in those municipalities where Indigenous communities reside. Having received approval from the Comissão de Direitos Humanos e Minorias (Human Rights and Minorities Commission) and, more recently, the Comissão de Cultura (Culture Commission), the next step on the path to enactment would be the approval of one more institutional body, the Comissão de Constituição e Justiça e de Cidadania (Commission of Constitution and Justice and of Citizenship) (Júnior, 2019). As of writing, the body has not granted approval to Bill 
3074/2019 (Portal da Câmara dos Deputados, 2019). Given the long delay of almost 1.5 years between commission approvals, most analysts consider the likelihood of this bill being ratified and implemented any time soon to be low.

Also relevant to our analysis of legislation in support of Indigenous peoples is Bill 2490/2007, which proposes a change to Brazilian Law 9.612, originally enacted in February 1998. Bill 2490/2007 aims to extend to Indigenous communities the right to provide community broadcasting services through a simplification of the licensing process and the associated documentation that must be submitted (see section 6 for details on the existing process). While by current Brazilian law a community radio can only be established by a nonprofit community foundation or association, this newer bill proposes to waive this requirement for Indigenous communities, ostensibly making community broadcasting more accessible (Portal da Câmara dos Deputados, 2007). Even though the bill was approved by all commissions, an appeal was subsequently filed in March 2010, and there has been no action or development since (Lacerda, 2016; Mesquita, 2018). Once again, potentially important legislation is languishing, leaving the broadcasting hopes of Indigenous communities in Brazil unfulfilled.

It is relevant to note that Brazil is home to a number of prominent institutes and think-tanks devoted to Indigenous activities, including some focussed on language documentation and revitalization. Founded in 1967, FUNAI is a Brazilian governmental protection agency for Indigenous interests which has an increasingly complex reputation as both facilitator and gatekeeper to Indigenous communities (Fundação Nacional do Índio [Funai], 2020). ${ }^{6}$ The Instituto Socioambiental (ISA, Socio-environmental Institute) was established in 1994 by Brazilian citizens committed to social, environmental and Indigenous rights and its branch, Povos Indígenas no Brasil (PIB, Indigenous Peoples in Brazil), generates important baseline data about Indigenous affairs (ISA, n.d.). Finally, the Instituto de Investigação e Desenvolvimento em Política Linguística (IPOL, Institute for Research and Development in Language Policy), is a nonprofit organization founded in 1999 which advocates for the linguistic and cultural rights of Brazil's linguistic communities in line with the Universal Declaration of Linguistic Rights. IPOL's stated mission is to develop projects that support communities of minority language speakers in Brazil and the Mercosul, assisting in the maintenance and promotion of Brazilian linguistic diversity (IPOL, n.d.). This, in brief, is the legislative and administrative framework within which Indigenous broadcasting in Brazil is struggling to develop and grow. 


\section{Media Penetration and Use in Brazil: Radio, Television, and the Internet}

We now turn to the operating space occupied by radio within the fastchanging broadcasting and communications landscape of Brazil. We are particularly interested in the use of radio in relation to the growth in television ownership and the increased penetration of the internet. As indicated by the numbers shown in Table 2 below, the percentage of Brazilians with access to radio devices has decreased significantly over the last decade, coinciding with-and likely the result of - the rapid growth of access to television and the internet. It is our experience, both anecdotal and analytical, that in urban centers at least, most Brazilians listen to the radio in constrained and quite specific environments: in their vehicles during

Table 2 Percentage of Brazilian Homes with Access ${ }^{\mathrm{a}}$ to Radio, Television, and the Internet from 1972 to 2019 according to IBGE Data. ${ }^{\text {b }}$

\begin{tabular}{cccc}
\hline Year & Radio & Television & Internet \\
\hline 2019 & - & $96.3 \%$ & $82.7 \%$ \\
2018 & - & $96.4 \%$ & $79.1 \%$ \\
2017 & - & $96.7 \%$ & $74.9 \%$ \\
2016 & $-^{c}$ & $97.2 \%$ & $69.3 \%$ \\
2015 & $69.2 \%$ & $97.1 \%$ & $57.8 \%$ \\
2014 & $72.1 \%$ & $97.1 \%$ & $54.9 \%$ \\
2013 & $75.7 \%$ & $97.2 \%$ & $48.0 \%$ \\
2012 & $80.9 \%$ & $97.2 \%$ & $40.3 \%$ \\
2011 & $83.4 \%$ & $96.9 \%$ & $36.6 \%$ \\
2009 & $87.8 \%$ & $95.6 \%$ & $27.4 \%$ \\
2008 & $88.9 \%$ & $95.1 \%$ & $23.8 \%$ \\
2007 & $88.0 \%$ & $94.3 \%$ & $20.0 \%$ \\
2006 & $87.8 \%$ & $92.9 \%$ & $16.8 \%$ \\
2005 & $88.0 \%$ & $91.4 \%$ & $13.6 \%$ \\
2004 & $87.7 \%$ & $90.2 \%$ & $12.2 \%$ \\
2001 & $88.0 \%$ & $89.0 \%$ & - \\
1996 & $90.4 \%$ & $85.2 \%$ & - \\
1992 & $84.9 \%$ & $74.6 \%$ & - \\
1988 & $81.8 \%$ & - & - \\
$1976^{\text {d }}$ & $75.9 \%$ & $46.6 \%$ & - \\
1972 & $61.9 \%$ & $32.0 \%$ & \\
\hline
\end{tabular}

${ }^{a}$ We ask readers to note that IBGE uses the terms "homes with tv / radio" and "access to tv / radio at home" interchangeably, creating ambiguity and classificatory confusion. For statistics relating to internet access, the government reports use the terms "use of internet in homes/at home" and "access to internet." Given that the distinction between ownership and access remains unclear in IBGE reports, we advise readers to exercise caution when citing these numbers.

bIBGE Library (IBGE, 2021) and IBGE Series (IBGE, n.d.).

CIBGE ceased collecting information about radio ownership in 2016.

${ }^{\mathrm{d}}$ The 1972 and 1976 data are drawn from Anuário Estatístico do Brasil -1980, p. 271, available from the IBGE archives, and do not include data for the states of Rondônia, Acre, Amazonas, Roraima, Pará, Amapá, Mato Grosso and Goiás. 
morning and evening commutes to and from work, during which time they might tune in to news or music, and at home when preparing meals or engaged in household chores.

Even though the data in Table 2 are incomplete-mostly on account of government reporting gaps-some revealing tendencies emerge. First, in the seven years between 2012 to 2019, internet access doubled, and now many Brazilians receive both television and radio services through broadband internet. Second, television ownership grew sharply in the 1990s, and has remained steady and high in the first decades of the 21 st century, indicating that the internet has not simply displaced television as a source for entertainment and information. Third, while radio ownership is certainly in decline, this should not be interpreted as necessarily indicating a reduction in radio listenership or audience.

As Brazilians have ever greater access to smartphones, smart televisions (with digital radio channels on demand) and computers in their homes (desktops, laptops, tablets and other forms of portable, handheld devices), dedicated radio-specific hardware is becoming increasingly redundanteven obsolete-with radio broadcasts easily located through streaming, podcasting or download services. Asking citizens whether they own a radio is rather like asking people whether they own an alarm clock: many will use its function without owning the actual hardware. In short, many Brazilians access radio and multimedia content through their cellphones, with the percentage of Brazilian citizens owning a cellphone for personal use more than doubling over ten years-from 36.6\% in 2005 to $78.3 \%$ in 2015 (IBGE, 2016), a figure that will certainly have increased at the time of writing in $2021 .^{7}$

In terms of internet penetration, around $83 \%$ of Brazilian homes have access to the internet, and $78 \%$ of Brazil's citizens above the age of 10 report using the internet regularly (IBGE, 2019). Rural areas have reduced internet access, and consequently have fewer reported users, with Brazil's North (home to most of Brazil's Indigenous territories) and Northeast (also home to many Indigenous communities) reporting the least access to internet services by region (Fundação Nacional do Índio [Funai], n.d.; IBGE, 2019). According to government statistics, $70.1 \%$ of Brazilian homes that have an internet connection used a computer to access the internet in 2015, a number that dropped to $45.1 \%$ in 2019 . On the other hand, $92.1 \%$ of those homes with internet used a cellphone to connect to online services in 2015, and that number rose to $99.5 \%$ in 2019 (IBGE, 2016, 2019). In terms of connection type, according to 2019 data, $81.2 \%$ of Brazilian homes that have internet access use mobile broadband to connect through $3 \mathrm{G}$ and $4 \mathrm{G}$ networks, while $77.9 \%$ subscribe to fixed broadband services (IBGE, 2019). As these statistics show, most Brazilians can and do access radio programming 
and livestreams through online services provided by their cell phones. We ask the reader to note that all of these statistics are collated and averaged at the national level, and that disaggregated data about radio penetration within and access for Indigenous communities in Brazil do not appear to be available.

\section{Speaking to the Nation: The Voice of Brazil}

The Brazilian state remains wedded to the value and importance of radio. Brazil is a global outlier for retaining the mandatory transmission of a government-supported radio program-broadcast in the nation's official language, Portuguese-for one hour every weekday, excluding national holidays, between the hours of 7:00pm and 10:00 pm on all national frequencies, (Agência Brasil, 2021) including community-run radio stations. Entitled A Voz do Brasil (The Voice of Brazil), and produced by Empresa Brasil de Comunicação, the country's public broadcaster, it is the oldest radio program in the country and the longest running in the Southern Hemisphere (Brandão, 2016).

Historically at least, A Voz do Brasil has been described as a public information service, bringing news updates, political analysis, and short interviews to the nation, although it has also served as a powerful platform for state propaganda and has never been aired in local, Indigenous languages. Founded in 1935, with the name Programa Nacional (National Program), it originally aired at $7 \mathrm{pm}$ and was initially used to transmit the cultural and political agenda of the government. The program became mandatory for all broadcasters in 1938, when it was renamed as A Hora do Brasil (The Brazil Hour), receiving its current title in 1962 (Portal da Câmara dos Deputados, 2015). In April 2018, the broadcast time slot was made more flexible by introducing a three-hour window for streaming of the program (Foreque \& Mazui, 2018). This was a response to broadcasters' complaints, who were eager to use the prime-time programming slot during the commuter rush hour to transmit their own content (Revista Época, 2010).

We suggest that simply continuing to broadcast mandatory content and hoping that it lands in willing ears is not the same as having a committed community of listeners. During the Bolsonaro regime, ${ }^{8}$ there is anecdotal evidence, from social media and our own networks, to indicate that listeners are tuning out of $A$ Voz do Brasil and finding political analysis and commentary elsewhere. Increasingly, Brazilians are turning to platforms such as WhatsApp, Facebook, Twitter, and YouTube to locate news that aligns with their political views and interests, even if some of the content on these and other platforms is of questionable legitimacy and veracity. 


\section{Establishing a Radio Station in Brazil: An Analysis of the Legislative Landscape}

Before turning to four compelling examples of Indigenous-run or Indigenous-focused radio stations in Brazil, we find it helpful to take stock of the legislative landscape for Indigenous media and assess what steps are involved in actually establishing a community radio station in the country. The practical steps in terms of what an applicant needs to demonstrate in order to submit the necessary paperwork to establish a radio station are onerous and demanding. What we have identified as the relative paucity of Indigenous-run radio stations in Brazil may be a direct consequence of a complex administrative processes that requires Presidential approval for the granting of a radio license. Notwithstanding the languishing draft legislation tabled to simplify the process for Indigenous communities to apply for radio licenses, the principal obstacle to further uptake may well be a bureaucratic system that is at once demotivating and inaccessible.

To establish a community radio station, the applicant must first submit an expression of interest. The Ministério da Ciência, Tecnologia, Inovações e Comunicações (MCTIC, The Ministry of Science, Technology, Innovation and Communication) periodically publishes notices with instructions for radio licensing. In order to be considered, an applicant must submit a series of documents including a granting/authorization request for a radio license; a copy of the entity's bylaws, updated and registered through a Notary's Office; minutes proving the constitution of the entity and the election of its directors (which function as a demonstration of governance, also formally registered at a Notary's Office); proof that all directors are of Brazilian nationality and legal adults (18+); a demonstration of support for the creation of a community radio signed by individuals and legal entities who have residence in the community; the registered address of a headquarters in the area of the community being served; and proof of payment of the registration fee - $100 \mathrm{BRL}[18.55 \mathrm{USD}]^{9}$ (Governo do Brasil, 2021). ${ }^{10}$

Once the documents are received, they are analyzed by the MCTIC and, if everything is deemed to be in order, the entity will be licensed. After that, the entity will have to present further documentation to complete the application process, including: a Station Operating Data Form and Technical Responsibility Note, signed by a legal representative of the entity and a qualified professional who will execute the technical aspects of the project; proof of enrollment in the Cadastro Nacional da Pessoa Jurídica (CNPJ, National Registry of Legal Entities); a debt clearance certificate managed by Agência Nacional de Telecomunicações (ANATEL, National Telecommunications Agency); a certificate attesting the entity's compliance with Social Security and with the Fundo de Garantia do Tempo de Serviço 
(FGTS, Severance Indemnity Fund); a joint clearance certificate of the entity's debts to comply with the Fazenda Federal (Federal Treasury) regulations; and a clearance certificate proving the absence of defaulted debts through the Justiça do Trabalho (Labor Court) (Governo do Brasil, 2021).

Once these additional documents have been assessed, if the entity is declared to be in compliance, the MCTIC will forward the file to the Minister of State, who will make a decision and, if positive, grant an Authorization Ordinance. After the publication of the Authorization Ordinance, the application is sent to the Office of the President, whofollowing additional review-will send it on to the National Congress. The Congress will deliberate on the file and if in favor, issue a Legislative Decree authorizing the entity to function as a Community Broadcasting Service for 10 years. After the MCTIC issues the broadcasting license, the community radio station is fully authorized to operate and broadcast (Governo do Brasil, 2021).

Given the many hurdles and requirements described above, it is unsurprising that many communities-and Indigenous groups in particular-still have no local, community-run radio stations. In fact, according to Santos, Prata, and Medeiros (2019), many communities with unlicensed and unregulated radio stations choose to remain in this illegal state precisely because of the "bureaucracy for granting authorizations, the daily costs of production and broadcasting, and the legal requirements of associative constitution" (p. 137). ${ }^{11}$

Should communities succeed in registering a radio station, they are technically free to manage their own organizational structure and programming, as long as the principal focus continues to benefit the community being served. In Brazilian law, under Decree 52.795 that regulates radio broadcast services, promulgated on December 31, 1963, article 66 notes that "criticism and unfavorable concepts are free, even if vehement, as well as the narrative of true facts, subject to the restrictions established by law, including acts of any of the powers of the State." ${ }^{\prime 2}$ In addition, Article 5 of the Brazilian constitution ${ }^{13}$ states that "the expression of thought is free" (item IV) and that "the expression of intellectual, artistic, scientific, and communications activities is free, independently of censorship or license" (item IX). By law, then, no government censorship on programming content is permitted, even if transmissions are critical of the current regime.

\section{Innovation and Connection: Examples of Indigenous Radios in Brazil}

Having outlined the linguistic background and reviewed the legislative context, we now compare and contrast four Indigenous radios currently broadcasting in Brazil. See Table 3 below for key points. What makes a radio station 
Table 3 Key Facts about Four of Brazil's Prominent Indigenous-focused Radio Stations

\begin{tabular}{|c|c|c|c|c|}
\hline Name & Rádio Yandê & Rede Wayuri & Rádio AJl & Copiô, Parente \\
\hline $\begin{array}{l}\text { Broadcast } \\
\text { platform }\end{array}$ & $\begin{array}{l}\text { Website, sometimes } \\
\text { other radio } \\
\text { stations }\end{array}$ & $\begin{array}{l}\text { SoundCloud, } \\
\text { Spotify }\end{array}$ & YouTube & $\begin{array}{l}\text { SoundCloud, } \\
\text { YouTube, } \\
\text { Spotify }\end{array}$ \\
\hline Established & November 2013 & November 2017 & April 2020 & March 2017 \\
\hline Headquarters & $\begin{array}{l}\text { Rio de Janeiro, Rio } \\
\text { de Janeiro }\end{array}$ & $\begin{array}{c}\text { São Gabriel da } \\
\text { Cachoeira, } \\
\text { Amazonas }\end{array}$ & $\begin{array}{l}\text { Dourados, Mato } \\
\text { Grosso do Sul }\end{array}$ & $\begin{array}{l}\text { Brasília, Distrito } \\
\text { Federal }\end{array}$ \\
\hline Program types & $\begin{array}{l}\text { Culture, Debate, } \\
\text { Conversation, } \\
\text { Music }\end{array}$ & $\begin{array}{l}\text { Culture, News, } \\
\text { Environment, } \\
\text { Politics }\end{array}$ & $\begin{array}{l}\text { News, Health } \\
\text { (public service } \\
\text { announcements) } \\
\text { Music }\end{array}$ & News, Politics \\
\hline $\begin{array}{l}\text { Does it } \\
\text { broadcast in } \\
\text { Indigenous } \\
\text { languages? }\end{array}$ & $\begin{array}{l}\text { Yes, in songs } \\
\quad \text { (languages vary) }\end{array}$ & $\begin{array}{l}\text { Has transmissions } \\
\text { recorded in } \\
\text { Indigenous } \\
\text { languages }^{b} \text { that } \\
\text { are sent to } \\
\text { more isolated } \\
\text { communities }\end{array}$ & $\begin{array}{l}\text { Yes, there are } \\
\text { announcements } \\
\text { and } \\
\text { participations } \\
\text { in Guarani }\end{array}$ & No \\
\hline Airtime $^{c}$ & $\begin{array}{l}\text { Streams } 24 / 7 \text {, on } \\
\text { their website }\end{array}$ & $\begin{array}{l}\text { Weekly } 15- \\
35 \text { minutes of } \\
\text { programming }\end{array}$ & $\begin{array}{l}\text { Weekly } 25- \\
40 \text { minutes of } \\
\text { programming }\end{array}$ & $\begin{array}{l}\text { Weekly } 10- \\
20 \text { minutes of } \\
\text { programming }\end{array}$ \\
\hline Financing & $\begin{array}{l}\text { Support comes from } \\
\text { donations of } \\
\text { friends, holding } \\
\text { talks at schools } \\
\text { and entities, and } \\
\text { selling merch } \\
\text { online. }\end{array}$ & $\begin{array}{l}\text { Support: FOIRN } \\
\text { Assistance: ISA } \\
\text { Production: } \\
\text { Rede Wayuri }\end{array}$ & $\begin{array}{l}\text { Support: IWGIA } \\
\text { Production: AJI } \\
\text { and GAPK }\end{array}$ & ISA \\
\hline $\begin{array}{l}\text { Other Outreach } \\
\text { and } \\
\text { Engagement }\end{array}$ & $\begin{array}{l}\text { Has an active } \\
\text { Facebook page. } \\
\text { Also broadcasts } \\
\text { audio bulletins } \\
\text { from Rede Wayuri }\end{array}$ & $\begin{array}{l}\text { Recordings are } \\
\text { also shared via } \\
\text { WhatsApp, } \\
\text { sound cars, and } \\
\text { flash drives }\end{array}$ & $\begin{array}{l}\text { Programs and news } \\
\text { are also shared } \\
\text { via an active } \\
\text { Facebook page. }\end{array}$ & $\begin{array}{l}\text { Newsletter from } \\
\text { Instituto } \\
\text { Socioambiental } \\
\text { (ISA) }\end{array}$ \\
\hline
\end{tabular}

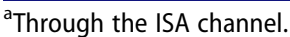

b(RSF, n.d.).

'All broadcasters offer occasional special editions which can have longer run times.

d(Orlandi, 2017).

e(Paiva, 2021).

"Indigenous" is a complicated question that can be answered in different ways. In our sample, we have included radios that are Indigenous-owned or managed and as well as stations that broadcast Indigenous-focussed content. Location, an additional feature that might have been more relevant in the past, is not so significant in this context as broadcasting is rapidly transitioning to web-based streaming and dissemination (Trigo-de-souza, 2002). In each of the following four case studies, geographical location is not a salient factor in determining a station's Indigenous credentials although it may be a factor impacting choices around the medium and language of transmission.

In selecting these four Indigenous-focused radio stations for inclusion in our analysis, our methodology has relied on access, availability and visibility in the public media, and across social media and in scholarly publications. Our 
selection is not representative of all Indigenous audio media in Brazil, but rather offers an illustrative snapshot of some of the most conspicuous Indigenous stations currently broadcasting. While we have been unable to locate data that identifies the number of Indigenous radio stations or programs active in Brazil, we understand that a small number of analogue radios stations dedicated to sharing culture and news within and between Indigenous communities are operating in rural areas and on official Indigenous territories. ${ }^{14}$ While this is an exciting development and one that certainly warrants additional investigation, establishing the extent of such stations-and understanding their broadcasting content-would require sustained fieldwork and community outreach, neither of which are viable during a global pandemic.

\section{Rádio Yandê}

Underscoring the declining relevance of physical location, Rádio Yandê ${ }^{15}$ is a prominent Indigenous-led radio station specialized in Indigenous content (mainly broadcast in Portuguese) that originated in Rio de Janeiro with contributors and collaborators from all over Brazil. Established in November 2013, and specializing in Indigenous cultural programming, discussions, debates, live conversations and music, the station has an active Facebook page, which supports its online, web-broadcasting platform. Rádio Yandê is known for being the first online Indigenous radio station in Brazil, and popular programs include several different genres of Indigenous music (in Indigenous and non-Indigenous languages) and programs from Brazil and abroad. Of the four radios we have reviewed and assessed, Rádio Yandê is the only station that broadcasts $24 / 7$, combining original content with programming generated by other stations and content producers, including audio bulletins from Rede Wayuri. Rádio Yandê was founded through a partnership between Indigenous communicators Anápuáka Muniz Tupinambá Hãhãhãe, Renata Machado Tupinambá (Aratykyra), and Denilson Baniwa (Rádio Yandê, n.d.).

In a number of Indigenous languages in the Tupi-Guarani family, the word Yandê means "us" (all of us including the listener or whomever is being addressed), underscoring the sense of a radio station designed for "you" and for "all of us" (Orlandi, 2017; Rádio Yandê, n.d.). According to the station's webpage, Rádio Yandề's main goal is to spread knowledge and understanding about Indigenous cultures in ways that integrate traditional perspectives with the reach and speed of the Internet, while at the same time working against old stereotypes and tired prejudices often propagated by nonIndigenous media about Indigenous peoples (Rádio Yandê, n.d.). Another of Rádio Yandềs stated objectives is to empower Indigenous individuals by providing space for cultural expression (through the sharing of stories, music and poetry), support collaborative communication (bringing together 
communities and Indigenous communicators across the country), and stimulate Indigenous entrepreneurship (through debates, interviews and talks). According to a news report from last year, Rádio Yandê reaches over a thousand listeners daily, in more than 40 countries (Brumatti, 2020), although we have no data about who those listeners are or why they tune in.

\section{Rede Wayuri}

Another successful Indigenous online broadcaster is Rede Wayuri, also known as Rede de Comunicadores Indígenas do Rio Negro, ${ }^{16}$ which streams Indigenous-focussed audio bulletins podcasts through SoundCloud (Podcast Wayuri) and Spotify (Audio Wayuri). The current podcast is a modern adaptation of Boletim Wayuri, a print-form newsletter which had for 20 years been distributed in the Rio Negro region, and which started broadcasting audio programs in November 2017 with a team based in São Gabriel da Cachoeira, Amazonas state. The word Wayuri comes from Nheengatu, one of the co-official Indigenous languages of the region, meaning "collective work" (Radler, 2020). Ranging from 15-35 minutes in duration, programs focus on cultural themes, Indigenous-related news, and environmental and political issues.

Although the broadcast language is usually Portuguese, Rede Wayuri also records transmissions in different Indigenous languages (Reporters Sans Frontières, n.d.), which are then disseminated to more isolated and remote communities. ${ }^{17}$ According to the Rede Wayuri webpage, content is also shared with interested communities and individuals via WhatsApp, flash drives, and "sound cars": vehicles kitted out with large speakers which drive through communities broadcasting content at high volume. Contact information is announced at the end of each program for those listeners interested in reaching out to the producers, whether to participate, ask questions, or request recordings of the program. According to their page, Rede Wayuri is supported by Federação das Organizações Indígenas do Rio Negro (FOIRN, Federation of Indigenous Organizations of Rio Negro) and receives additional assistance from ISA. Rede Wayuri has partnerships with Rádio Yandê, UNICEF, and with a journalism agency, Amazônia Real (FOIRN, n.d.). In 2020, Rede Wayuri was selected as one of 30 "Information Heroes" around the globe, an initiative managed by Reporters Sans Frontières (RSF, Reporters Without Borders) to pay tribute to journalists and media communicators fighting disinformation and helping to save lives during the COVID-19 pandemic (Reporter Sans Frontières [RSF], 2020). 


\section{Rádio AJI}

Operating in a similar format is Rádio AJI, a station founded in April of 2020 in Dourados, Mato Grosso do Sul state. An Indigenous-led initiative, Rádio AJI currently streams its weekly 25-40 minutes of content on YouTube in a structure that includes news, health announcements (currently related to COVID-19) and Indigenous music. Although much of the program is streamed in Portuguese, some announcements are in Guarani, an Indigenous language spoken by the local community on the Reserva Indígena de Dourados. ${ }^{18}$ Programs are produced by Ação Jovens Indígenas (AJI, Young Indigenous Action) and Grupo de Apoio aos Povos Kaiowá Guarani (GAPK), with support from the International Work Group for Indigenous Affairs (IWGIA).

While Rádio AJI programs began to stream on YouTube only recently, according to a local news report, $A J I$ team members started producing content in 2011 (Dourados News, 2011). Their program, entitled Programa Ore Reko, meaning "our way of living," included music, interviews, and miscellaneous content about Indigenous peoples across Brazil, as well as creative works by members of the AJI collective. Led by broadcaster Emerson Machado, the program streamed for 45 min every Saturday afternoon on Rádio Grande FM (92,1) (Dourados News, 2011).

\section{Copiô, Parente}

Copiô, Parente, by contrast, is not led entirely by Indigenous peoples, although it is exclusively focused on topics of interest to Indigenous and forest peoples (including Quilombolas and Ribeirinhos). ${ }^{19}$ The program broadcasts from the federal capital, Brasília. The first podcast aired in March 2017, and its episodes, streamed in Portuguese, are all available on SoundCloud, Spotify and YouTube. Content mainly includes news and politics relating to Indigenous issues, and programs cover government decisions and recent events in Brasília that affect Indigenous peoples. Copiô, Parente is an initiative managed by Instituto Socioambiental (ISA), and it releases weekly podcasts of around 10-20 minutes each. In 2018, Copiô, Parente hosted a series of interviews called "Copiô, Candidat@?," an elections special filled with questions from communities and answers by the aspiring presidential candidates in the 2018 elections, and focussed on individual rights and socioenvironmental topics (Leite, 2018).

Copiô, Parente is a Portuguese phrase, meaning "did you copy, kin?," with the term parente (kin, in-group, relative) being frequently used by Indigenous peoples to address one another. ${ }^{20}$ While its episodes are short, the listenership of Copiô, Parente has remained consistently high, reflected in the hundreds of views that their content generates on YouTube. Podcasts of 
episodes are also shared in MP3 format via WhatsApp with about 2,000 contacts in Indigenous and forest communities, or people who work closely with these communities. Reaching at least 60 communities in Pará state and Amazonas state, the program is also rebroadcast by Central de Rádio de Altamira, in Pará, and Central de Radiofonia da FOIRN, in São Gabriel da Cachoeira, Amazonas state. Those two radio stations extend Copiô, Parente's reach to more isolated regions without stable internet (Leite, 2018).

\section{Summary and Comparisons}

From this brief comparison of four Indigenous-focussed radio stations broadcasting in Brazil, we may draw some very preliminary conclusions. First, even though there are a few online radio stations and podcasts that are led by or focussed on Indigenous communities, most of these still work through the medium of Portuguese rather than in one or more languages native to the community. Second, while the relative paucity of Indigenous language programming and broadcasting in Brazil is certainly worth further study and consideration, a number of factors have likely come together to inhibit development in this space, including: a restrictive and challenging legislative and bureaucratic operating framework; different strategic priorities within Indigenous communities who may be focussed more on environmental and territorial encroachment by industry and the state; relatively few trained personnel positioned to deliver radio programming in Indigenous languages; and a deliberate decision to use the majority languagePortuguese-to build a more inclusive listener community that would reach both Indigenous and non-Indigenous audiences who are not conversant in an Indigenous language.

At the time of writing (July 2021), conflict between the Brazilian state and Indigenous communities has escalated sharply and is being widely reported in the international media. Reviewing viewing numbers of the online programs through SoundCloud and YouTube, we note with interest that there was a significant increase in audience numbers between April 2021 and June 2021, with Copio, Parente growing from 215 views in April to 2,343 views in June (a ten-fold increase), and Rádio AJI going from 35 views in April to 60 views in May (a 70\% increase). ${ }^{21}$ One of the videos distributed through the AJI Facebook page, reporting the arrival of donations of food baskets in the community, reached over 1,400 views. ${ }^{22}$ While Rádio Yandê offers no live analytics or data about the listenership of its stream, some of the videos on their Facebook page from the last 3 months have reached more than 50,000 views, suggesting substantial audience engagement. 


\section{Conclusion: Constraints and Opportunities}

Our goal in this comparative review has been to assess the structural conditions within Brazil that both support and impede developments in Indigenous-language radio programming in terms of access to radio, provision of content and medium of dissemination. Our preliminary findings indicate that a very cumbersome and alienating legislative context for granting radio licenses combined with the high number of under-resourced Indigenous languages spoken within Brazil's borders pose significant challenges to the further development and implementation of Indigenous language broadcasting.

In noting this, we do not wish to imply that linguistic diversity is itself an obstacle to successful Indigenous radio programming. It is not, and in fact we unequivocally view linguistic diversity and the richness of Indigenous languages as a precondition for successful Indigenous programming. At issue, rather, is the profound absence of government support in further developing this fertile space for creativity in media and an increasingly hostile, antiIndigenous political climate in which Indigenous issues and rights are perceived by the current regime as orthogonal to the national interest.

In the absence of inclusive legislation, financial resources, grants and pathways for Indigenous communities in Brazil to activate their rights to free expression and self-determination, the relative scarcity of Indigenousfocussed media is unsurprising. In light of these profound challenges and an antagonistic legislative framework, the continued operations and commitment to broadcasting shown by Rádio Yandê, Rede Wayuri, Rádio AJI, Copiô, Parente and other Indigenous-focused stations in Brazil are praiseworthy and impressive, offering a powerful story of resilience and resistance within a harsh operating environment. We uplift and recognize the commitments of these Indigenous radios and their dedicated staff, and celebrate their endurance and persistence in broadcasting information relevant to Indigenous communities.

The media space in Brazil is fast changing, and the presence or absence of community radio serves as a revealing indicator of wider questions of access, empowerment, and inclusion. As Santos et al. (2019) note, in Brazil "the regions that historically have the worst social indicators in the countryNorth and Northeast-are those that proportionally have fewer municipalities with official community radio stations." ${ }^{23}$ While we have identified some of the obstacles to the further development of Indigenous-focused radio in this article, we choose to end on a note of hope, recognizing the growing strength of social media and online spaces supporting Indigenous causes, rights, advocacy and self-determination. ${ }^{24}$ Without wanting to identify specific platforms, we note high levels of political engagement and cultural sharing through newer forms of social media, both in Portuguese 
and also in languages Indigenous to Brazil. With this, we conclude that digital technologies are productively re-energizing traditional media formats, including radio. Further research may wish to explore whether it is productive to consider a public service announcement produced in Guarani, a prominent Indigenous language, streamed through SoundCloud and downloadable from YouTube to be "radio," or rather as Kischinhevsky (2016) has suggested, a manifestation of "expanded radio." Newer digital media-in Indigenous spaces in particular-challenge traditional binaries such as medium and message (McLuhan, 1964) in ways that are exciting and necessary.

\section{Funding}

This work was supported by a University of British Columbia Work Learn International Undergraduate Research Award.

\section{Notes}

1. The last sentence in the excerpt is a direct quote from Francy Júnior.

2. "So, why capitalize 'Indigenous'? It articulates and identifies a group of political and historical communities, compared to the lower case 'i,' which can refer to anyone. For example, being born in Ludington, I'm 'indigenous' to Michigan, but I'm not an 'Indigenous person' from Michigan” (Weeber, 2020).

3. We ask the reader to note that the last national Brazilian census was in 2010, and while the next census had been scheduled for 2020, it was subsequently postponed. In 2021, the government did not approve the census budget, and without dedicated resources, no census can be conducted. Plans are currently being drawn up to conduct the census in 2022 (Richter, 2021).

4. Fundação Nacional do Índio (National Indian Foundation).

5. On the EGIDS scale, "dying" languages are those where "the only fluent users (if any) are older than child-bearing age, so it is too late to restore natural intergenerational transmission through the home; a mechanism outside the home would need to be developed" (Eberhard et al., 2021).

6. Many activists are critical of the "new FUNAI" which is perceived to be working against the interests of Indigenous peoples through increased political interference (see Milhorance, 2021).

7. Accessing publicly-available IBGE data sources, we attempted to identify the percentage of Indigenous Brazilians who own cellphones with internet capability and broadband access but were unsuccessful in our search for granular and disaggregated data.

8. From January 2019 until the time of writing, Jair Bolsonaro has served as president of Brazil. A retired military officer and a conservative politician unaffiliated with any established political party, his administration has been marked by toxic polemic, contentious decisions and a profound disregard for needs and rights of all minorities, including but not limited to Indigenous peoples. 
9. The currency conversion to United States Dollars follows the exchange rates of September 27, 2021. While the actual amount may seem trivial to those in the global north, it is a significant investment for rural and less affluent communities in Brazil.

10. The information described in this section about the application process to register a community radio is taken from https://www.gov.br/pt-br/servicos/ radcom, a government page, which we have translated from Portuguese.

11. Our translation. The original text reads: "Pela burocracia para concessão de outorgas, pelos custos do cotidiano de produção e veiculação e pelas exigências legais de constituição associativa."

12. Our translation. The original text reads: "São livres as críticas e os conceitos desfavoráveis, ainda que veementes, bem como a narrativa de fatos verdadeiros, guardadas as restrições estabelecidas em lei, inclusive de atos de qualquer dos poderes do Estado."

13. English version retrieved from Superior Tribunal Federal (Superior Tribunal Federal [STF], 2020).

14. We note that many rural and remote areas in Brazil can be understood as "zones of silence" (Medeiros, 2020), for having no easy access to radio or tv broadcast signals.

15. www.radioyande.com

16. Our translation: Network of Indigenous Communicators of Rio Negro.

17. Regrettably, specific languages and community names are not listed in this publication and no further details are available.

18. Our translation: Dourados Indigenous Reserve.

19. Quilombolas refer to the people who live in Quilombos, settlements of AfroBrazilians (sometimes mixed with people of Indigenous heritage) descended mainly from fugitive slaves, who have formed communities in rural or forested areas. Ribeirinhos are traditional rural communities who live near rivers, with fishing and farming as cornerstones of their livelihood.

20. A short video (in Portuguese) by Vitor Vulga, a young member of the Indigenous Pataxó community, explains how and why Indigenous peoples in Brazil use the word parente: https://www.instagram.com/reel/ CSNHNWQpmRh/?utm_medium=copy_link

21. These numbers were calculated based off YouTube episodes with the highest viewing numbers for the respective months, as of July 26, 2021.

22. Facebook page: AJI - Ação dos Jovens Indígenas de Dourados. Video: "Comitiva Esperança em Dourados na entrega de cestas básicas."

23. Our translation. The original Portuguese reads: "As regiões que historicamente apresentam piores indicadores sociais no país - Norte e Nordeste - são as que proporcionalmente têm menos municípios com rádios comunitárias oficializadas."

24. In the course of scoping, research and writing this contribution, from May to September 2021, we attempted to reach out to individuals and groups whom we identified as responsible for or in leadership positions within the radio stations we selected to review in this paper. Despite multiple attempts through multiple platforms over several months, we were unable to make connections. Any further research in this area would benefit greatly from engagement with the founders and broadcasters themselves in order to better understand the obstacles that Indigenous communicators face when running a radio station in Brazil. 


\section{Acknowledgments}

This article has benefitted significantly from constructive criticism and important suggestions offered by colleagues at the University of British Columbia, specifically Mark Johnson, Raiane Salles and Hannah Wittman. In addition, we are extremely grateful to the two anonymous peer reviewers whose generous and specific recommendations have further strengthened this contribution. We thank journal editor Anne MacLennan and the editorial staff associated with the Journal of Radio \& Audio Media for this opportunity. All remaining errors and inconsistencies are our own.

\section{Disclosure Statement}

No potential conflict of interest was reported by the author(s).

\section{Notes on contributors}

Natália Oliveira Ferreira graduated with a BA in Linguistics from the University of British Columbia (UBC), Vancouver. Her research interests include Indigenous languages, lexicography, and language revitalization. She has worked as a research assistant for two linguistics labs and participated in a fieldwork project to study comparative structures in Secwepemctsín, an Indigenous language of British Columbia. She is a member of the Latin American Languages Lab (LaLaLab), a student-led research group at UBC, and of the Relational Lexicography project. At present, she works as a research assistant in the Institute for Critical Indigenous Studies at UBC.

Mark Turin is a linguistic anthropologist and an Associate Professor cross-appointed between the Department of Anthropology and the Institute for Critical Indigenous Studies at the University of British Columbia, Canada. He directs the Digital Himalaya Project and the World Oral Literature Project, and has been working in collaboration with the Thangmi-speaking communities of Eastern Nepal and Darjeeling district in India since 1996, and with the Heiltsuk First Nation community on the west coast of British Columbia, Canada, since 2014. Turin has written and presented two BBC Radio series on language endangerment and policy: Our Language in Your Hands and On Language Location. Turin's research is focused on language reclamation, revitalization, documentation, and conservation; language mapping, policies, politics, and language rights; and orality, archives, digital tools and technology. He is the author or coauthor of four books, the editor of 12 volumes, and edits a series on oral literature.

\section{ORCID}

Natália Oliveira Ferreira (D) http://orcid.org/0000-0002-8589-2153

Mark Turin (D) http://orcid.org/0000-0002-2262-0986 


\section{References}

Agência Brasil. (2021, July 22) A Voz do Brasil 86 anos: Conheça quem faz o programa. https://agenciabrasil.ebc.com.br/geral/noticia/2021-07/voz-do-brasil -86-anos-conheca-quem-faz-o-programa

Anderson, H., Backhaus, B., Fox, J., \& Bedford, C. (2020). Fifty years of resistance and representation: A historical account of Australian community radio. Journal of Radio \& Audio Media, 27(2), 234-254. doi:10.1080/19376529.2020.1754827

Associated Press in Rio de Janeiro. (2021, May 28). Brazilian wildcat miners attack police and burn indigenous homes in Amazon. The Guardian. https://www.the guardian.com/world/2021/may/28/brazil-wildcat-miners-police-indigenousamazon?CMP=Share_iOSApp_Other

First People's Cultural Council [FPCC], Bliss, H., Gessner, S., Herbert, T., \& Parker, A. (2020, May). Framing the discussion: A proposal for a national strategy for the implementation of bill C-91. Retrieved July 29, 2021, from https://fpcc.ca/ wp-content/uploads/2020/08/FPCC_national_strategy_discussion_paper_June_ 11_2020.pdf

Brandão, M. (2016, October 31). A Voz do Brasil estreia hoje em novo formato. Agência Brasil. https://agenciabrasil.ebc.com.br/geral/noticia/2016-10/voz-dobrasil-estreia-hoje-em-novo-formato

Brumatti, G. (2020, April 19). Do jornalismo à 'sofrência': Conheça a primeira rádio indígena online do Brasil. G1. https://g1.globo.com/sp/campinas-regiao/terra-dagente/noticia/2020/04/19/do-jornalismo-a-sofrencia-conheca-a-primeira-radioindigena-online-do-brasil.ghtml

Cabral, A. S. A. C., de Araújo Sampaio, W. B., \& Sinha, V. D. S. (2016). Indigenous language policies in Brazil: Training indigenous people as teachers and researchers. In Endangered languages and languages in danger: Issues of documentation, policy, and language rights (pp. 45-59). Benjamins.

Chikaipa, V., \& Gunde, A. M. (2020). The role of community radio in promotion of indigenous minority languages and cultures in Malawi. Journal of Radio \& Audio Media, 1-17. doi:10.1080/19376529.2020.1751633

Costa Alves, T. (2020). Music and identity in a postcolonial world: Radio airplay of lusophone music in public service broadcasting in the portuguese-speaking world. Journal of Radio \& Audio Media, 27(1), 39-53. doi:10.1080/ 19376529.2019 .1689243

Crevels, M. (2012). Language endangerment in South America: The clock is ticking. The Indigenous Languages of South America: A Comprehensive Guide, 167, 234.

Danos, D., \& Turin, M. (2021). Living language, resurgent radio: A survey of indigenous language broadcasting initiatives. Language Documentation \& Conservation, 15, 75-152.

Demuyakor, J. (2021). Achieving active political pluralism and participation through development communication: The role of local and community radio media outlets in Northern Ghana. Journal of Radio \& Audio Media, 1-22. doi:10.1080/ 19376529.2021.1915317

Dourados News. (2011, December 6) Programa indígena chama atenção em rádio de Dourados. https://www.douradosnews.com.br/dourados/programa-indigenachama-atencao-em-radio-de-dourados/70523/ 
Eberhard, D. M., Simons, G. F., \& Fennig, C. D. (2021). Brazil. Ethnologue: Languages of the world (24th ed.). Dallas: Texas: SIL International. https://www.ethnologue. com/country/BR

Federação das Organizações Indígenas do Rio Negro [FOIRN]. (n.d.) Rede Wayuri. Retrieved July 8, 2021, from https://foirn.org.br/rede-de-comunicadoresindigenas-do-rio-negro/

Foreque, F., \& Mazui, G. (2018, April 4). Temer sanciona lei que flexibiliza horário de transmissão do programa de rádio. A Voz do Brasil. G1. https:/g1.globo.com/ politica/noticia/temer-sanciona-lei-que-flexibiliza-transmissao-do-programa-deradio-a-voz-do-brasil.ghtml

Funai - Fundação Nacional do Índio. (2020, November 27). A Funai. https://www. gov.br/funai/pt-br/acesso-a-informacao/institucional/Institucional

Funai - Fundação Nacional do Índio. (n.d.). Terras indígenas: O que é? [Indigenous lands: What is it?]. Retrieved June 11, 2021, from http://www.funai.gov.br/index. $\mathrm{php} /$ nossas-acoes/demarcacao-de-terras-indigenas

Governo do Brasil. (2021, March 26). Obter autorização para exercer serviço de Radiodifusão Comunitária (RADCOM) [To obtain authorization to exercise Community Broadcasting service (RADCOM)]. Retrieved June 10, 2021, from https://www.gov.br/pt-br/servicos/radcom

IBGE - Instituto. Brasileiro de Geografia e Estatística(2021) Biblioteca: Catálogo. https://biblioteca.ibge.gov.br/biblioteca-catalogo.html

IBGEeduca. (2021). Conheça o Brasil - População - Indígenas. Retrieved July 7, 2021, from https://educa.ibge.gov.br/jovens/conheca-o-brasil/populacao/20506indigenas.html

Instituto Brasileiro de Geografia e Estatística [IBGE]. (2012, August 10). Censo 2010: População indígena é de 896,9 mil, tem 305 etnias e fala 274 idiomas [Census 2010: Indigenous population is of 896.9 thousands, has 305 ethnicities and speaks 274 languages] https://censo2010.ibge.gov.br/noticias-censo?busca=1\&id=3\&idnoti cia $=2194 \& v i e w=$ noticia\#: : :text=Em\%202010\%2C\%20293\%2C9\%20mil,34\% 2C1\%20mil\%20pessoas

Instituto Brasileiro de Geografia e Estatística [IBGE]. (2016). Pesquisa Nacional por Amostra de Domicílios (PNAD): Acesso à Internet e à televisão e posse de telefone móvel celular para uso pessoal 2015. https://agenciadenoticias.ibge.gov. br/media/com_mediaibge/arquivos/617a4c9e499e4a828fe781592e62c864.pdf

Instituto Brasileiro de Geografia e Estatística [IBGE]. (2019). Pesquisa Nacional por Amostra de Domicílios Contínua (PNAD Contínua): Acesso à Internet e à televisão e posse de telefone móvel celular para uso pessoal 2019. https://biblioteca.ibge.gov. br/visualizacao/livros/liv101794_informativo.pdf

Instituto Brasileiro de Geografia e Estatística [IBGE]. (n.d.) Séries Históricas e Estatísticas. https://seriesestatisticas.ibge.gov.br/series.aspx?vcodigo=PD282

Instituto de Investigação e Desenvolvimento em Política Linguística [IPOL]. (n.d.) Sobre o IPOL. Retrieved August 3, 2021 from http://ipol.org.br/sobre-o-ipol/ .

Instituto Socioambiental [ISA]. (n.d.) Povos Indígenas no Brasil. Retrieved June 2, 2021. from https://www.socioambiental.org/pt-br/o-isa/programas/povosindigenas-no-brasil

Jimenez, C. (2019). Antenna dilemmas: The rise of an indigenous-language low-power radio station in Southern California. Journal of Radio \& Audio Media, 26(2), 247-269. doi:10.1080/19376529.2018.1481847 
Júnior, J. (2019, December 11). Comissão aprova projeto que torna idioma indígena língua cooficial em municípios com aldeias [Commission approves project that makes indigenous language a co-official language in municipalities with villages]. Agência Câmara de Notícias. https://www.camara.leg.br/noticias/625266comissao-aprova-projeto-que-torna-idioma-indigena-lingua-cooficial-emmunicipios-com-aldeias/

Kischinhevsky, M. (2016). Rádio e mídias sociais: Mediações e interações radiofônicas em plataformas digitais de comunicação. Mauad Editora Ltda.

Krenak, E. (2021, June 17) The new form of colonization of indigenous lands in Brazil: Drug cartels and militias. Cultural Survival. Retrieved July 8, 2021, from https://www.culturalsurvival.org/news/new-form-colonization-indigenous-landsbrazil-drug-cartels-and-militias

Lacerda, R. F. (2016). Radiodifusão Sonora Comunitária em Terras Indígenas: Os obstáculos da colonialidade na legislação de RadCom. In J. G. S. Júnior, M. C. Ramos, E. C. Geraldes, F. O. Paulino, J. Souza, H. M. de Paula, ... V. Negrini (Eds.), O Direito Achado na Rua: Introdução Crítica ao Direito à Comunicação e à Informação (pp. 317-323). Brasília: FAC-UnB.

Leite, L. (August 24, 2018) Copiô, Candidat@? ISA - Instituto Socioambiental. https://www.socioambiental.org/pt-br/blog/blog-do-ppds/copio-candidat

Massini-Cagliari, G. (2004). Language policy in Brazil: Monolingualism and linguistic prejudice. Language Policy, 3(1), 3-23. doi:10.1023/B:LPOL.0000017723.72533.fd

Massini-Cagliari, G. (2006). One language among many, many languages in one: Monolingualism, linguistic prejudice and language policy in Brazil. Revista da ANPOLL, 1(20), 63-84. doi:10.18309/anp.v1i20.475

McLuhan, M. (1964). Understanding media: The extensions of man. New York: McGraw-Hill.

Medeiros, R. (2020). Função Social do Rádio Local Entre Desertos de Notícia e Zonas de Silêncio: Reverberações da migração AM-FM. Âncora: Revista Latinoamericana de Jornalismo, 7(1), 360-378. doi:10.22478/ufpb.2359375X.2020v7n1.51319

Mesquita, G. B. (2018). Rádio Comunitária e povos indígenas: Entraves e potencialidades para pluralidade de vozes. Revista Interritórios, 4(7), 76-88. doi:10.33052/inter.v4i7.238209

Milhorance, F. (2021, May 13). Brazilian police target indigenous leaders after government criticism. The Guardian. https://www.theguardian.com/world/2021/ may/13/brazil-police-indigenous-leaders-covid-jair-bolsonaro

Ministry for Culture and Heritage (2020, July 30) History of the Māori language. New Zealand History. https://nzhistory.govt.nz/culture/maori-language-week/historyof-the-maori-language

Moore, D., \& Galucio, A. V. (2016). Perspectives for the documentation of indigenous languages in Brazil. Language Documentation and Revitalization in Latin American Contexts, 1, 29-58.

Morello, R. (2021, February 15). Lista de línguas cooficiais em municípios brasileiros. IPOL. Retrieved May 31, 2021, from http://ipol.org.br/lista-de-linguas-cooficiaisem-municipios-brasileiros/

Naknanuk, K. (2021, June 24) Repression by the police in Brazil, as Bill PL 490 threatens indigenous rights. Cultural Survival. Retrieved July 8, 2021, from https:// www.culturalsurvival.org/news/repression-police-brazil-bill-pl-490-threatensindigenous-rights 
Orlandi, A. P. (2017, February) Rádio Yandê: Cultura indígena para o mundo. Goethe-Institut. https://www.goethe.de/ins/br/pt/kul/sup/fut/20914561.html

Paiva, V. (March 8, 2021) Rede Wayuri: O coletivo de jornalismo criado por jovens indígenas que faz toda a diferença na Amazônia. Hypeness. https://www.hypeness. com.br/2021/03/rede-wayuri-o-coletivo-de-jornalismo-criado-por-jovensindigenas-que-faz-toda-a-diferenca-na-amazonia/

Phillips, T., \& Milhorance, F. (2021, May 27) Brazil aerial photos show miners' devastation of indigenous people's land. The Guardian. https://www.theguar dian.com/global-development/2021/may/27/brazil-aerial-photos-revealdevastation-by-goldminers-on-indigenous-land?CMP=Share_iOSApp_Other

Pine, A., \& Turin, M. (2017). Language Revitalization. Language Revitalization. In Oxford Research Encyclopedia of Linguistics. Oxford University Press.

Portal da Câmara dos Deputados. (2007, November 27) Projeto de Lei 2490/2007. Retrieved May 31, 2021, from https:/www.camara.leg.br/proposicoesWeb/fichade tramitacao?idProposicao $=378269$

Portal da Câmara dos Deputados. (2015, July 22) A Voz do Brasil está no ar há 80 anos. https://www.camara.leg.br/radio/programas/465232-a-voz-do-brasil-estano-ar-ha-80-anos/

Portal da Câmara dos Deputados. (2019, May 22) Projeto de Lei 3074/2019. Retrieved May 31, 2021, from https://www.camara.leg.br/proposicoesWeb/fichadetramita cao?idProposicao $=2204433$

Povos Indígenas no Brasil. (n.d.). Línguas. Retrieved May 28, 2021, from https:/pib. socioambiental.org/pt/L\%C3\%ADnguas

Prado, M. (2012). História do rádio no Brasil. Livros De Safra.

Rádio Yandê. (n.d.). A Rádio. Retrieved July 26, 2021, from https://radioyande.com/

Radler, J. (November 3, 2020) Rede Wayuri comemora três anos de comunicação indígena no Rio Negro. Instituto Socioambiental. https:/www.socioambiental.org/ pt-br/noticias-socioambientais/rede-wayuri-comemora-tres-anos-decomunicacao-indigena-no-rio-negro

Reporter Sans Frontieres [RSF]. (2020, June 15). Coronavirus “information heroes" Journalism that saves lives. Retrieved July 8, 2021, from https://rsf.org/en/news/ coronavirus-information-heroes-journalism-saves-lives

Reporter Sans Frontieres [RSF]. (n.d.) Rede Wayuri. Retrieved August 3, 2021 from https://rsf.org/pt/rede-wayuri

Revista Época. (2010, July 3). A Voz do Brasil: Um programa fora de sintonia. http:// revistaepoca.globo.com/Revista/Epoca/0,EMI152378-15223,00-A+VOZ+DO +BRASIL+UM+PROGRAMA+FORA+DE+SINTONIA.html

Richter. (2021, May 14) STF decide que censo deverá ser realizado em 2022. Agência Brasil. https://agenciabrasil.ebc.com.br/justica/noticia/2021-05/stf-decide-quecenso-devera-ser-realizado-em-2022

Rodrigues, A. D. I. (1993). Línguas indígenas: 500 anos de descobertas e perdas. DELTA: Documentação E Estudos Em Linguística Teórica E Aplicada, 9, 1.

Rodrigues, A. D. I. (2015). Linguística: As línguas indígenas do Brasil. Fragmentum, (46), 289-299.

Santos, E., Prata, N., \& Medeiros, R. (2019). Rádios comunitárias no Brasil: Entre a clandestinidade e a relevância social. Chasqui: Revista Latinoamericana de Comunicación, (140), 129-146. 
Santos, I. (2019, May 14). Rádio, internet e redes sociais viram aliados de comunicadores populares [Radio, internet and social media become allies of popular communicators]. Amazônia Real. https://amazoniareal.com.br/radio-internet-e-redessociais-viram-aliados-de-comunicadores-populares/

Shulist, S. (2017). Transforming indigeneity: Urbanization and language revitalization in the Brazilian Amazon. University of Toronto Press.

Steinfeld, N., \& Laor, T. (2019). New arenas or more of the same? Public and commercial radio stations on Facebook. Journal of Radio \& Audio Media, 26(2), 194-209. doi:10.1080/19376529.2018.1431890

Superior Tribunal Federal [STF]. (2020). Constitution of the Federative Republic of Brazil. Retrieved August 3, 2021, from http://www.stf.jus.br/arquivo/cms/ legislacaoConstituicao/anexo/brazil_federal_constitution.pdf

Trigo-de-souza, L. M. (2002). Rádios. internet. br: O rádio que caiu na rede. Revista USP, (56), 92-99. https://www.revistas.usp.br/revusp/article/download/33810/ 36548

Tron, M. S. (2021, February 2) Radio indígena en México: Un hito de resistencia. Más de México. https://masdemx.com/2021/02/radio-indigena-mexico-comunitarioimportancia/

Turin, M. (2019, December 6). Rising voices: Recognising and revitalising indigenous languages is central to addressing the legacies of historical injustice. The Association of Commonwealth Universities (ACU). https://www.acu.ac.uk/the-acu-review/ris ing-voices/

Turin, M., \& Pine, A. (2019, June 24). Using technology to help revitalize indigenous languages. OUPblog. https://blog.oup.com/2019/06/using-technology-helprevitalize-indigenous-languages/

Weeber, C. (2020, May 19) Why capitalize “indigenous"? Sapiens https://www. sapiens.org/language/capitalize-indigenous/

Wilson, W. H. (2014). Hawaiian: A Native American language official for a state. In Handbook of heritage, community, and native American languages in the United States (pp. 233-242). Routledge. 